\title{
Prediction of biological activity of spiroquinazolone derivatives as protein kinase inhibitors FGFR1 and CK2
}

\author{
O. K. Farat ${ }^{D} \mathrm{C}, \mathrm{D}, \mathrm{E}, \mathrm{S}$. A. Varenychenko*A-E, V. I. Markov ${ }^{\mathrm{E}, \mathrm{F}}$ \\ Ukrainian State University of Chemical Technology, Dnipro, Ukraine
}

A - research concept and design; B - collection and/or assembly of data; C - data analysis and interpretation; D - writing the article;

$\mathrm{E}$ - critical revision of the article; $\mathrm{F}$ - final approval of the article

The purpose. The search for FGFR1 and CK2 protein kinase inhibitors were performed among spiroquinazolone derivatives using receptor-oriented virtual screening and in vitro biochemical testing using the human CK2 kinase domain.

Materials and methods. The docking was performed at ATP binding sites for protein kinases CK2 and FGFR1 using the Autodock4 program. The inhibitory activity of the studied compounds against the protein kinase CK2 was determined by the inclusion of a phosphate group-containing radioactive ${ }^{32} \mathrm{P}$ in the peptide substrate when it was phosphorylated by the kinase in the presence of $\mathrm{Y}^{3}{ }^{32} \mathrm{P}-\mathrm{ATP}$.

Results. Testing results for the selected compounds showed that when added to an $\mathrm{IC}_{50}$ concentration of $10 \mu \mathrm{M}$, the protein kinase residual activity was more than $45 \%$.

Conclusions. The results of the analysis of LogP and LogS indicated that the optimization of spiroquinazolone derivatives should be carried out in the direction of increasing the hydrophobicity of these compounds.

\section{Прогноз біологічної активності похідних спірохіназолонів як інгібіторів протеїнкіназ FGFR1 і CK2}

\section{О. К. Фарат, С. А. Варениченко, В. І. Марков}

Мета роботи - пошук інгібіторів протеїнкіназ FGFR1 і СК2 серед похідних спірохіназолонів за допомогою рецепторно-орієнтованого віртуального скринінгу та біохімічного тестування in vitro, використовуючи кіназний домен СК2 людини.

Матеріали та методи. Докінг виконали в АТФ-зв'язувальні сайти протеїнкіназ CK2 та FGFR1 за допомогою програми Autodock4. Інгібувальну активність досліджуваних сполук щодо протеїнкінази СК2 визначали за включенням фосфратної групи, що містить

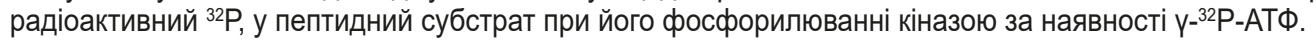

Результати. Результати тестування серед обраних сполук показали, що при їх додаванні в концентрації IC ${ }_{50} 10 \mu \mathrm{M}$ залишкова активність протеїнкінази становить понад $45 \%$.

Висновки. Результати аналізу показників LogP i LogS дають змогу зробити висновок, що оптимізацію похідних спірохіназолонів потрібно здійснювати в напрямі збільшення гідрофобності цих сполук.

Ключові слова: похідні спірохіназолонів, інгібітори протеїнкіназ, рецепторно-орієнтований віртуальний скринінг, біохімічні процеси, in vitro методи.

Актуальні питання фрармацевтичної і медичної науки та практики. 2020. Т. 13, № 1(32). С. 84-90

Прогноз биологической активности производных спирохиназолонов в качестве ингибиторов протеинкиназ FGFR1 и CK2

\section{О. К. Фарат, С. А. Варениченко, В. И. Марков}

Цель работы - поиск ингибиторов протеинкиназ FGFR1 и СК2 среди производных спирохиназолонов с помощью рецепторно-ориентированного виртуального скрининга и биохимического тестирования in vitro с использованием киназного домена СК2 человека.

Материалы и методы. Докинг проводили в АТФ-связывающие сайты протеинкиназ CK2 и FGFR1 с помощью программы Autodock4. Ингибирующая активность исследованных соединений относительно протеинкиназы СК2 определена по включению фосфорной группы, содержащей радиоактивный ${ }^{32}$ Р, в пептидный субстрат при его фоссрорилировании киназой в присутствии $\gamma^{3}{ }^{32}$ Р-АТФ.

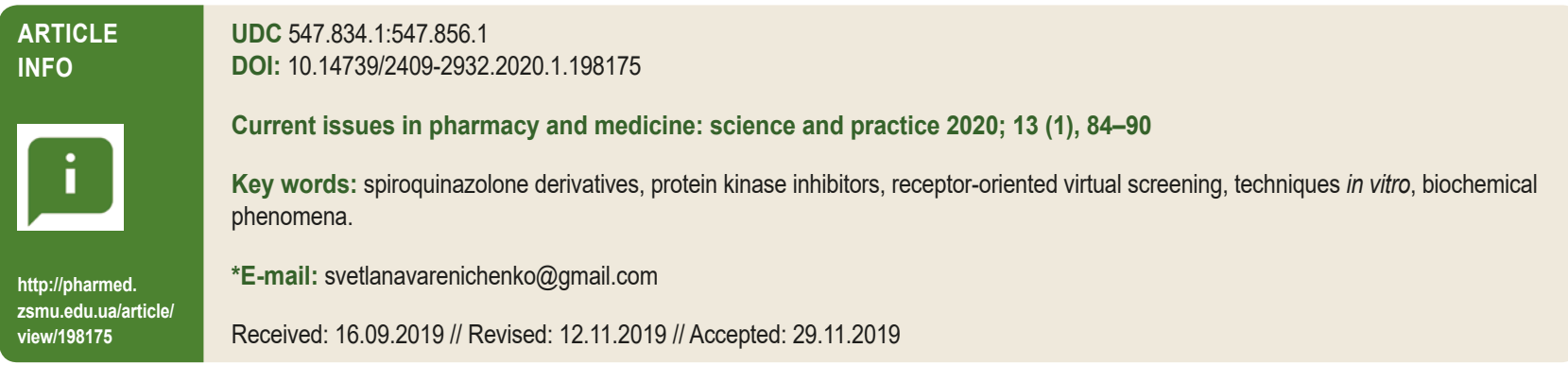


Результаты. Результаты тестирования среди выбранных соединений показали, что при добавлении в концентрации IC ${ }_{50} 10 \mu \mathrm{M}$ остаточная активность протеинкиназы составляет $45 \%$.

Выводы. Результаты анализа показателей LogP и LogS позволяют сделать вывод: оптимизацию производных спирохиназолонов необходимо проводить в направлении увеличения гидрофобности этих соединений.

Ключевые слова: производные спирохиназолонов, ингибиторы протеинкиназ, рецепторно-ориентированный виртуальный скрининг, биохимические процессы, методы in vitro.

Актуальные вопросы фрармацевтической и медицинской науки и практики. 2020. Т. 13, № 1(32). С. 84-90

Among the important tasks of the modern science and pharmaceutical industry is the search and development of new biologically active compounds. The leading position is occupied by the search for highly effective drugs for cancer treatment $[1,2]$.

An important target in the therapy of various cancers is the fibroblast growth factor receptor 1 (FGFR1) [3] and the protein kinase CK2 [4]. FGFR1 plays a crucial role in the development of cancer by enhancing a point mutation or translocation. The increase or activation of FGFR1 has been reported in many cancers [5]. There is strong evidence that CK2 plays a role in the pathogenesis of cancer [6]. CK2 can regulate major cellular processes, many of which are deregulated in cancer cells. In particular, CK2 increases cell reproduction [7], cell growth [8] and cell survival [9], alters cell morphology [10], enhances cellular transformation, and promotes angiogenesis [11]. Given the role of FGFR1 and CK2 in the development and progression of cancer, these protein kinases have been selected for further receptor-oriented virtual screening as a molecular target.

Effective CK2 inhibitors have been found among various classes of chemical compounds [7,8], for example among coumarins [9], flavonoids [10], quinoline [11] and quinolone [12], pyrimidinones [13] and chromenone [14]. It is known that in the second stage of clinical studies, there is only one compound CXX4945 as an anticancer drug [15].

In this way, the search for effective inhibitors of the protein kinase FGFR1 and CK2 does not lose its relevance. Quinazolone derivatives are known for their biological activity in biomedical chemistry, in particular as one of the classes of receptor protein kinase inhibitors [16-20].

\section{Aim}

To search for new low-molecular-weight inhibitors of protein kinase FGFR1 and CK2, virtual screening of a collection of compounds and biochemical testing of in vitro selected substances was performed among quinazolone derivatives.

\section{Materials and methods}

Molecular docking. Receptor-based virtual screening was used to analyze the binding of the compound collection. Docking was performed at ATP-binding sites of protein kinases CK2 (database code RCSB 3NSZ - 1.30尺̊) Ta FGFR1

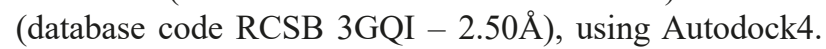
The structures taken for docking were kinase domains in the active state.
Ligands were ranked by kinase domain binding energy. This was done using the Autodock4 scoring function. The Autodock4 scoring function estimated the free binding energy of the ligand with the receptor in $\mathrm{kcal} / \mathrm{mol}$, smaller values corresponded to more potent inhibitors. There was also information on the presence of hydrogen bonds between the ligand and the receptor, which were characteristic of known inhibitors of the protein kinases studied. The vast majority of inhibitors are characterized by the presence of hydrogen bonds with the hinge region of the kinase domain, which combines the $\mathrm{N}$ and $\mathrm{C}$ end domains and participates in the binding of the natural substrate - ATP. Hydrogen bonds with the conservative lysine, asparagine, and glutamine residues involved in the catalytic transfer of the phosphate group were also evaluated. It is also characteristic of many protein kinase inhibitors. A visual evaluation of the ligand at the binding site was performed to remove compounds having an unrealistic position on the ATP-binding site.

Visual analysis. A visual analysis of the results of molecular docking (interaction of compounds with the amino acid residues of CK2 and FGFR1 ATP-binding site) was carried out in the Discovery Studio Visualizer 4.0 (http://accelrys. com/).

In vitro testing. The total volume of the reaction mixture was $30 \mu \mathrm{l}$. Initially, $0.5 \mathrm{ml}$ of peptide substrate solution (RRRDDDSDDD (New England Biolabs), $135 \mu \mathrm{M}), 15.5$ $\mathrm{ml}$ of water and $0.05 \mu \mathrm{l}$ of protein kinase solution $(0.01$ of relative protein kinase activity) were added to $3 \mu$ of reaction buffer (prepared by adding $200 \mathrm{mM}$ of Tris- $\mathrm{HCl}$ (pH 7.5), 500 $\mathrm{mM}$ of $\mathrm{KCl}, 100 \mathrm{mM}$ of $\mathrm{MgCl}_{2}$ ). Then, $1 \mathrm{ml}$ of inhibitor was added at the desired concentration and after 3 minutes, the reaction was started by adding another $10 \mathrm{ml}$ of $150 \mu \mathrm{M}$ of ATP solution, which also contained $1 \mu \mathrm{Ci}$ of $\gamma$-labeled ${ }^{32} \mathrm{PATP}$, to $20 \mathrm{ml}$ of the reaction mixture. The final concentration of ATP in the reaction mixture was $50 \mathrm{mCi} / \mathrm{mmol}$. Incubation time was $30 \mathrm{~min}$ at $30^{\circ} \mathrm{C}$. The reaction was stopped by adding 8 $\mu \mathrm{l}$ of $5 \%$ phosphoric acid. The whole volume of the sample was transferred to Whatman P81 phosphocellulose paper filters, which were washed with $0.75 \%$ phosphoric acid three times for $5 \mathrm{~min}$. The filters were dried and their radioactivity was measured on a PerkinElmerTri-Carb 2800-TR scintillation counter. A sample of $1 \mu \mathrm{l}$ of dimethyl sulfoxide (DMSO) was used as a negative control instead of the inhibitor. The degree of inhibition of protein kinase was determined by the ratio of ${ }^{32} \mathrm{P}$ inclusion with the inhibitor and in its absence. 


\section{Results}

14 compounds were isolated for the protein kinase CK2 and FGFR1 with the least free binding energy according to the scoring function (Tables 1,2) and the presence of hydrogen bonds with the corresponding amino acid residues, which are characteristic of kinase inhibitors (Fig. 1, 2). These compounds were highly likely to be inhibitors of their respective receptors.

Compounds 1 and 8 were synthesized following a published method [21]. Authors have studied in detail the Mannich aminoalkylation reaction of 5',6', 7', ,' -tetra-

Table 1. The least free binding energy of compounds for the protein kinase FGFR1

\begin{tabular}{|c|c|c|c|c|c|}
\hline № & Structure & Score & № & Structure & Score \\
\hline $1^{21}$ & & -7.39 & $8^{21}$ & & -6.73 \\
\hline $2^{22}$ & & -7.04 & $9^{22}$ & & -6.63 \\
\hline $3^{23}$ & & $\mid-6.92$ & $10^{24}$ & & -6.54 \\
\hline $4^{24}$ & & -6.87 & $11^{22}$ & & -6.5 \\
\hline $5^{25}$ & & -6.81 & $12^{22}$ & & -6 \\
\hline $6^{26}$ & & -6.79 & $13^{22}$ & & -5.84 \\
\hline $7^{22}$ & & -6.77 & $14^{26}$ & & -5.74 \\
\hline
\end{tabular}


hydro-1'H,3'H-spiro-[cyclohexane-1,2-quinazolin]-4'-one with primary amines containing different aliphatic and heterocyclic substituents. The structure of the aminoalkylation products 2 and 7 were proved by ${ }^{1} \mathrm{H}$ NMR spectroscopy and by elemental analysis. Heating the aminoalkylation products with a $10 \%$ solution of hydrochloric acid gave the carboxamides 9, 11-13 [22]. Compounds 3, 5 and 10 were synthesized by the method described in literature [23-25].

The spectroscopic parameters agreed with those in the literature. Refluxing cyclohexanone-2-carboxamide with ammonium acetate and cyclopentanone in toluene with azeotropic distillation of water gives the spiran 6 and refluxing cyclohexanone-2-carboxamide with ammonium acetate - compound 14. The structures of compounds were confirmed by ${ }^{1} \mathrm{H}$ NMR, mass spectra and elemental analysis [26].

The formation of two hydrogen bonds was due to the interaction of the oxygen atoms and the hydrogen atoms of the amide group of compound 3 (Fig. 1, Table 1) and

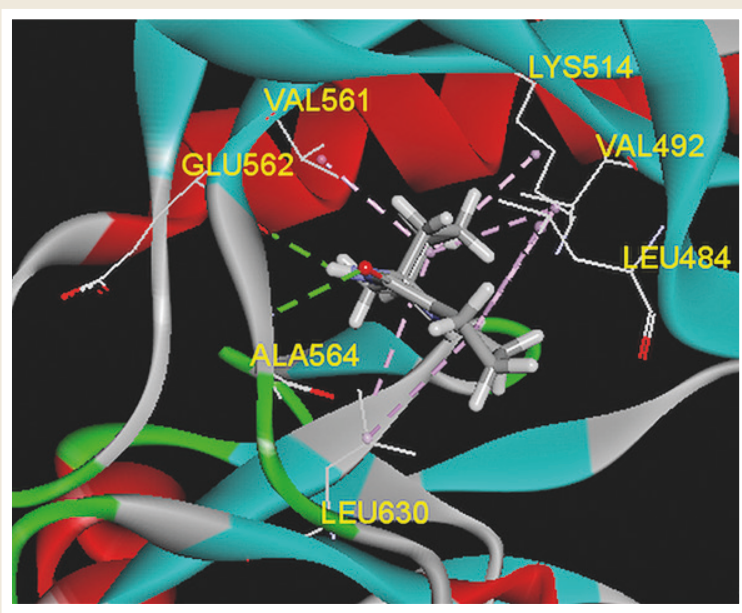

Fig. 1. Ligand complex of compound 3 (Table 1) at the ATP-binding site of receptor FGFR1 (model of the complex obtained by molecular docking, hydrogen bonds are shown in green dashed line).

Table 2. The least free binding energy of compounds for the protein kinase СК2

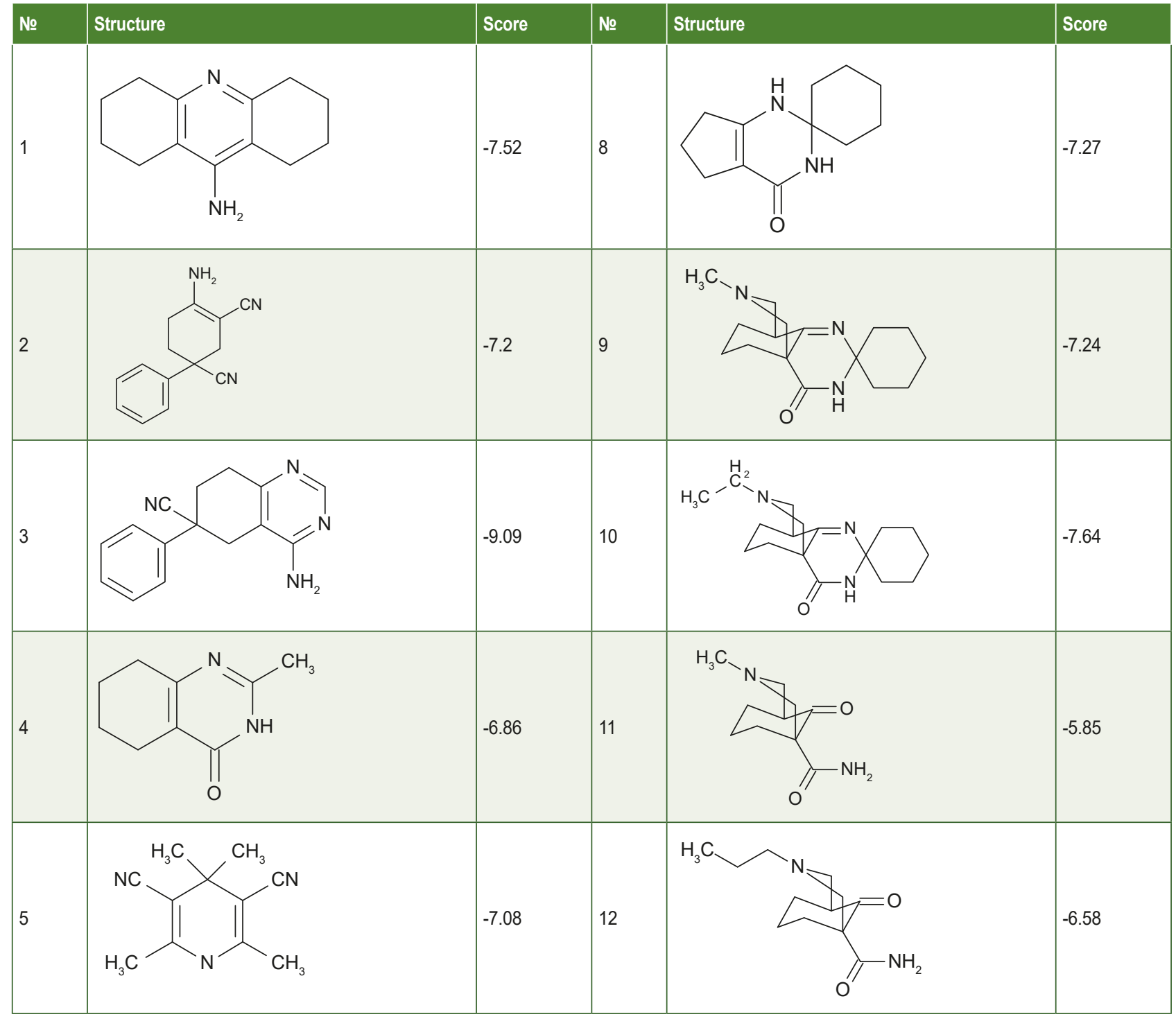


Cont. table 2

So Structure

the amino acid residues GLU562 and ALA564. Compound 3 formed hydrophobic contacts with the amino acid residues LEU630, VAL561, LYS514.

Hydrogen atoms of the $\mathrm{NH}_{2}$-group of ligand 3 (Fig. 2, Table 2) and the amino acid residue GLU114 were involved in the formation of the hydrogen bond. Ligand 3 formed hydrophobic contacts with the amino acid residues ILE174, VAL66, LYS68.

The selected 14 compounds were tested in vitro using the human CK2 kinase domain. All potential inhibitors met Lipinski's rules [27].

The inhibitory activity of the studied compounds against the protein kinase CK2 was determined by the inclusion of a phosphate group containing incorporation of radiolabeled phosphate ${ }^{32} \mathrm{P}$ into a peptide substrate with its phosphorylation with the kinase in the presence of $\left[\gamma_{-}{ }^{32} \mathrm{P}\right] \mathrm{ATP}$.

No more detailed studies were conducted for this sample because the residual protein kinase activity was more than $45 \%$ when added to the selected compounds.

The materials added indicated the structures of the compounds and the residual activity of the protein kinase CK2 when added at a concentration $\left(\mathrm{IC}_{50}, \mu \mathrm{M}\right)$ of $10 \mu \mathrm{M}$ (Table 3).

\section{Discussion}

Biochemical tests showed that compound 1 was the most active. At a concentration of $10 \mu \mathrm{M} 1$, it inhibited the activity of protein kinase by $21 \%$. This is not enough though, more than $50 \%$ is required.

The average calculated $\log P$ for the compounds tested was 1.74 and did not exceed 3 (compound 3 ). The average value of $\operatorname{LogS}$ was -2.84 , and its maximum value -4.2 was in compound 3 .

According to the analysis of the calculated indicators $\log \mathrm{P}$ and $\operatorname{LogS}$, we can conclude that the optimization of spiroquinazolone derivatives should be carried out in the direction of increasing the hydrophobicity of these compounds. This, in turn, should improve the inhibitory activity of the compounds.

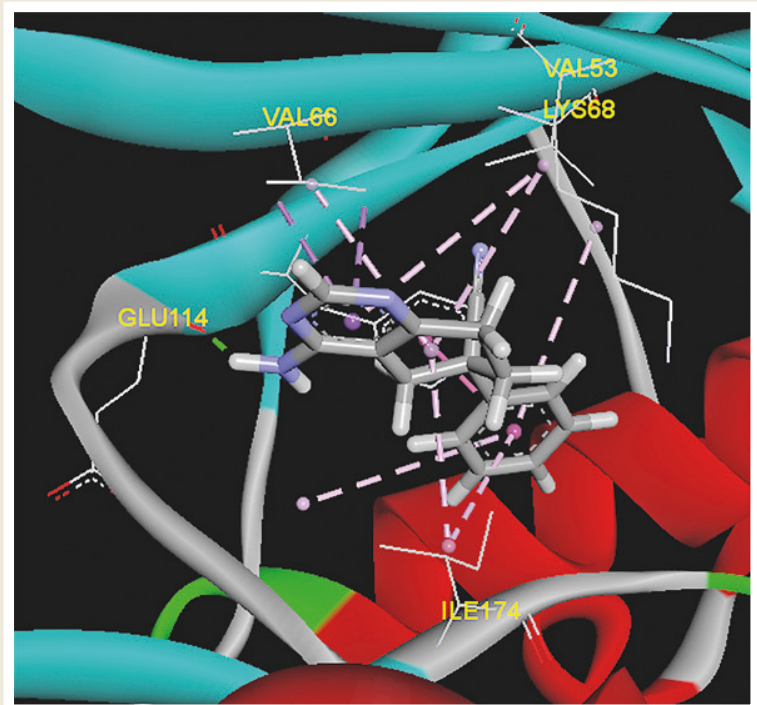

Fig. 2. Ligand complex of compound 3 (Table 2) at the ATP-binding site of receptor CK2 (model of the complex obtained by molecular docking, hydrogen bonds are shown in green dashed line).

Table 3. The residual activity of the protein kinase CK2 for the structures of the compounds

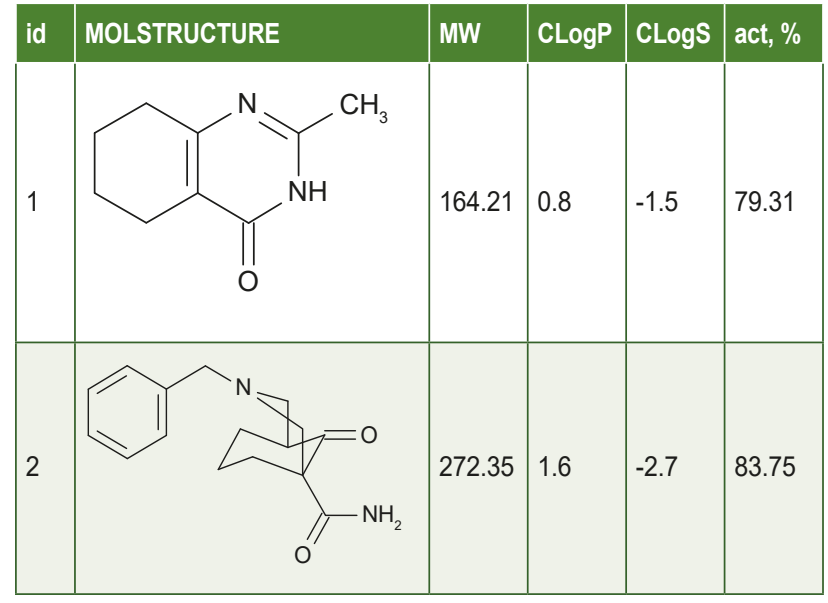


Cont. table 3

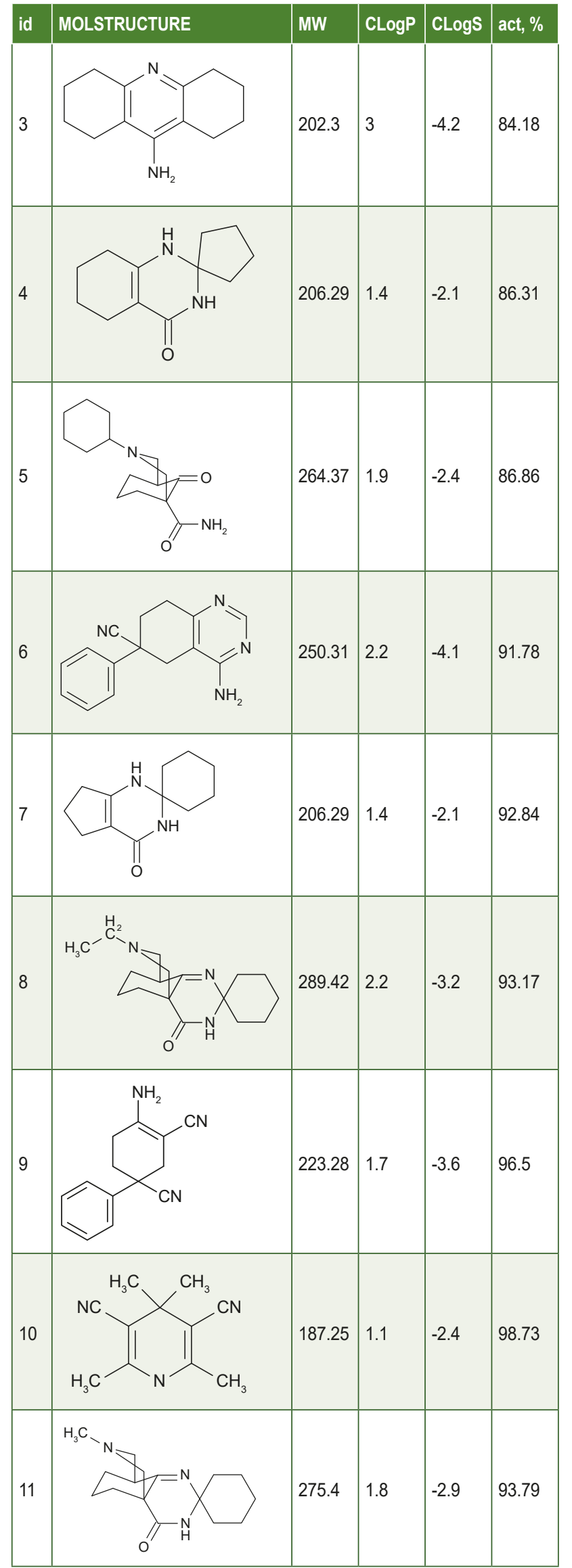

\section{Conclusions}

As a result of receptor-oriented virtual screening of spiroquinazolone derivatives, 14 compounds have been selected for protein kinases CK2 and FGFR1. In vitro biochemical tests have shown that the residual protein kinase activity, when added to selected compounds, is more than $45 \%$. The results of the analysis of $\log P$ and $\operatorname{LogS}$ have indicated that the optimization of spiroquinazolone derivatives should be carried out in the direction of increasing the hydrophobicity of these compounds.

\section{Acknowledgements}

The authors thank Prof. Serhii Yarmoliuk from the Institute of Molecular Biology and Genetics NAS of Ukraine for the help in organization of virtual screening and biochemical testing.

Conflicts of interest: authors have no conflicts of interest to declare. Конфлікт інтересів: відсутній.

Information about authors:

Farat O. K., PhD, Researcher, Department of Technology of Organic Substances and Pharmaceuticals, Ukrainian State University of Chemical Technology, Dnipro, Ukraine.

ORCID ID: 0000-0002-3603-2720

Varenychenko S. A., PhD, Associate Professor, Department of Technology of Organic Substances and Pharmaceuticals, Ukrainian State University of Chemical Technology, Dnipro, Ukraine.

Markov V. I., DSc, Professor, Department of Technology of Organic Substances and Pharmaceuticals, Ukrainian State University of Chemical Technology, Dnipro, Ukraine.

Відомості про авторів:

Фарат О. К., канд. хім. наук, науковий співробітник каф. технології органічних речовин та фармацевтичних препаратів,

ДВНЗ «Український державний хіміко-технологічний університет», м. Дніпро, Україна.

Варениченко С. А., канд. хім. наук, доцент каф. технології органічних речовин та фармацевтичних препаратів,

ДВНЗ «Український державний хіміко-технологічний університет»,

м. Дніпро, Україна.

Марков В. І, д-р хім. наук, професор каф. технології органічних речовин та фармацевтичних препаратів, ДВНЗ «Український державний хіміко-технологічний університет», м. Дніпро, Україна.

\section{Сведения об авторах:}

Фарат О. К., канд. хим. наук, научный сотрудник каф. технологии органических веществ и фармацевтических препаратов

ГВУЗ «Украинский государственный химико-технологический университет», г. Днипро, Украина.

Варениченко С. А., канд. хим. наук, доцент каф. технологии органических веществ и фармацевтических препаратов,

ГВУЗ «Украинский государственный химико-технологический университет», г. Днипро, Украина.

Марков В. И., д-р хим. наук, профессор каф. технологии органических веществ и фармацевтических препаратов, ГВУЗ «Украинский государственный химико-технологический университет», г. Днипро, Украина.

\section{References}

[1] Hernandez, D. C., \& Vyas, P. (2019). Oncogenic Drivers and Development. Cancer Discovery, 9(12), 1653-1655. https://doi. org/10.1158/2159-8290.cd-19-1082

[2] Obeng, E. A., Stewart, C., \& Abdel-Wahab, O. (2019). Altered RNA Processing in Cancer Pathogenesis and Therapy. Cancer Discovery, 9(11), 1493-1510. https://doi.org/10.1158/2159-8290.cd-19-0399 
[3] Xu, C. C., Li, W. L., Qiu, P. H., Xia, Y. Q., Du, X. J., Wang, F., ... $\mathrm{Li}, \mathrm{X}$. K. (2015). The therapeutic potential of a novel non-ATP-competitive fibroblast growth factor receptor 1 inhibitor on gastric cancer. Anti-Cancer Drugs, 26(4), 379-387. https://doi.org/10.1097/ cad. 0000000000000195

[4] Chua, M. M. J., Ortega, C. E., Sheikh, A., Lee, M., Abdul-Rassoul, H., Hartshorn, K. L., \& Dominguez, I. (2017). CK2 in Cancer: Cellular and Biochemical Mechanisms and Potential Therapeutic Target. Pharmaceuticals, 10(1), Article Unsp 18. https://doi.org/10.3390/ph10010018

[5] Andre, F., Arnedos, M., Baras, A. S., Baselga, J., Bedard, P. L., Berger, M. F., ... Consortium, A. P. G. (2017). AACR Project GENIE: Powering Precision Medicine through an International Consortium. Cancer Discovery, 7(8), 818-831. https://doi.org/10.1158/2159-8290. cd-17-0151

[6] Trembley, J. H., Wu, J. J., Unger, G. M., Kren, B. T., \& Ahmed, K. (2013). CK2 suppression of apoptosis and its implication in cancer biology and therapy. Protein kinase CK2 (pp. 319-343). https://doi. org $/ 10.1002 / 9781118482490 . c h 12$

[7] Ahmed, K., Davis, A. T., Wang, H. M., Faust, R. A., Yu, S. H., \& Tawfic, S. (2000). Significance of protein kinase CK2 nuclear signaling in neoplasia. Journal of Cellular Biochemistry, 130-135.

[8] Litchfield, D. W. (2003). Protein kinase CK2: structure, regulation and role in cellular decisions of life and death. Biochemical Journal, 369, 1-15. https://doi.org/10.1042/bj20021469

[9] Ahmad, K. A., Wang, G. X., Unger, G., Slaton, J., \& Ahmed, K. (2008). Protein kinase CK2-A key suppressor of apoptosis. Advances in Enzyme Regulation, Vol 48, 48, 179-187. https://doi.org/10.1016/j. advenzreg.2008.04.002

[10] Filhol, O., Deshiere, A., \& Cochet, C. (2013). Role of CK2 in the control of cell plasticity in breast carcinoma progression. Protein kinase CK2 (pp. 363-382) https://doi.org/10.1002/9781118482490.ch14

[11] Montenarh, M. (2014). Protein Kinase CK2 and Angiogenesis. Advances in Clinical and Experimental Medicine, 23(2), 153-158. https:// doi.org/10.17219/acem/37040

[12] Sarno, S., Papinutto, E., Franchin, C., Bain, J., Elliott, M., Meggio, F., ... Pinna, L. A. (2011). ATP Site-Directed Inhibitors of Protein Kinase CK2: An Update. Current Topics in Medicinal Chemistry, 11(11), 13401351. https://doi.org/10.2174/156802611795589638

[13] Prykhod'ko, A. O., Dubinina, G. G., Golovach, S. M., Yarmoluk, S. M. (2004). Inhibitory proteinkinazy SK2 [Inhibitors of protein kinase CK2] Ukrainica Bioorganica Acta, (1-2), 39-48. [in Ukrainian].

[14] Chilin, A., Battistutta, R., Bortolato, A., Cozza, G., Zanatta, S., Poletto, G., ... Moro, S. (2008). Coumarin as attractive casein kinase 2 (CK2) inhibitor scaffold: An integrate approach to elucidate the putative binding motif and explain structure-activity relationships. Journal of Medicinal Chemistry, 51(4), 752-759. https://doi.org/10.1021/ jm070909t

[15] Lolli, G., Cozza, G., Mazzorana, M., Tibaldi, E., Cesaro, L., Donella-Deana, A., ... Pinna, L. A. (2012). Inhibition of Protein Kinase CK2 by Flavonoids and Tyrphostins. A Structural Insight. Biochemistry, 51(31), 6097-6107. https://doi.org/10.1021/bi300531c

[16] Syniugin, A. R., Ostrynska, O. V., Chekanov, M. O., Volynets, G. P., Starosyla, S. A., Bdzhola, V. G., \& Yarmoluk, S. M. (2016). Design, synthesis and evaluation of 3-quinoline carboxylic acids as new inhibitors of protein kinase CK2. Journal of Enzyme Inhibition and Medicinal Chemistry, 31, 160-169. https://doi.org/10.1080/1475636 6.2016 .1222584

[17] Golub, A. G., Yakovenko, O. Y., Bdzhola, V. G., Sapelkin, V. M., Zien, P., \& Yarmoluk, S. M. (2006). Evaluation of 3-carboxy-4(1H)-quinolones as inhibitors of human protein kinase CK2. Journal of Medicinal Chemistry, 49(22), 6443-6450. https://doi.org/10.1021/jm050048t

[18] Chekanov, M. O., Ostrynska, O. V., Tarnavskyi, S. S., Synyugin, A. R., Briukhovetska, N. V., Bdzhola, V. G., . . Y Yarmoluk, S. M. (2014). Design, synthesis and biological evaluation of 2-aminopyrimidinones and their 6-aza-analogs as a new class of CK2 inhibitors. Journal of Enzyme Inhibition and Medicinal Chemistry, 29(5), 639-646. https:/l doi.org/10.3109/14756366.2013.837898

[19] Prykhod'ko, A. O., Yakovenko, O. Y., Golub, A. G., Bdzhola, V. G., \& Yarmoluk, S. M. (2005). Evaluation of 4H-4-chromenone derivatives as inhibitors of protein kinase CK2. Biopolymers and Cell, 21(3), 287292. https://doi.org/10.7124/bc.0006F4

[20] Chon, H. J., Bae, K. J., Lee, Y., \& Kim, J. (2015). The casein kinase 2 inhibitor, CX-4945, as an anti-cancer drug in treatment of human hematological malignancies. Frontiers in Pharmacology, 6, Article 70. https://doi.org/10.3389/fphar.2015.00070

[21] Varenichenko, S. A., Farat, O. K., Markov, V. I. (2013). Sintez novykh proizvodnykh 2-spirokhinazolonov [Synthesis of New Derivatives of 2-Spiroquinazolones]. Voprosy khimii i khimicheskoi tekhnologii, (6), 28-31. [in Russian].

[22] Markov, V. I., \& Farat, O. K. (2012). 5',6', 7', 8'-Tetrahydro-1'H,3'H-spiro cyclohexane-1,2'-quinazolin -4'-one in Mannich reaction. Chemistry of Heterocyclic Compounds, 48(6), 925-930. https://doi.org/10.1007/ s10593-012-1078-z

[23] Shi, D. X., Qian, D. F., Zhang, Q., \& Li, J. R. (2009). Cyclohexanespiro-2'-2, 3',6',7'-tetrahydro-1'H-cyclopenta d pyrimidin-4'(5'H)-one. Acta Crystallographica Section E-Crystallographic Communications, 65, O615-U2652. https://doi.org/10.1107/s1600536809005388

[24] Upadysheva, A. V., Grigor'eva, N. D., Ryabokobylko, Yu. S., Znamenskaya, A. P. (1983). Recyclization of 2,2-disubstituted 4(3H)-oxo- and 4-chloro-1,2-dihydropyrimidines to 4-aminopyridine derivatives. Chemistry of Heterocyclic Compounds, 19(1), 95-100. https://doi.org/10.1007/BF00512825

[25] Paleček, J., \& Kuthan, J. (1974). Zur N-Alkylierung von 1,4-Dihydropyridinderivaten. Zeitschrift Für Chemie, 14(8), 308-309. https://doi. org/10.1002/zfch.19740140807

[26] Markov, V. I., Farat, O. K., Varenichenko, S. A., Velikaya, E. V., Zubatyuk, R. I., \& Shishkin, O. V. (2013). Synthesis and Formylation of Substituted 2-Spiropyrimidin-4-ones and Related Compounds. Chemistry of Heterocyclic Compounds, 49(8), 1158-1165. https://doi. org/10.1007/s10593-013-1358-2

[27] Lipinski, C. A., Lombardo, F., Dominy, B. W., \& Feeney, P. J. (2001). Experimental and computational approaches to estimate solubility and permeability in drug discovery and development settings (Reprinted from Advanced Drug Delivery Reviews, vol 23, pg 3-25, 1997). Advanced Drug Delivery Reviews, 46(1-3), 3-26. https://doi.org/10.1016/ s0169-409x(00)00129-0 